\title{
新潟県におけるウミスズメの幼鳥
}

\author{
風間辰 夫*
}

1980 年 7 月 26 日, 新潟県生活環境部自然保護課へウミスズメSynthliboramphus antiquus （幼鳥）の保護依頼があり, 現場に行き収容した後, 新潟県傷病鳥救護舎で保護飼育したが 5 日目に落鳥した (Fig. 1)。

本種の幼鳥が新潟県で発見されたのは初めてであり, 北海道を除いた日本海側にも繁殖地が あるのではないかと考觉られるので, 新潟紧野生鳥獣生態研究会では, 粟島, 佐渡等で調查中 であるが，ひとまず一報し参考に供したい。

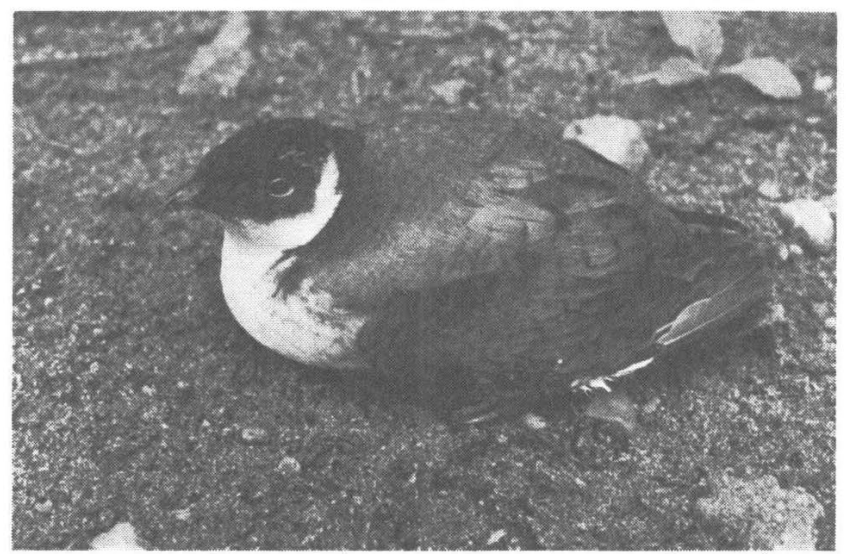

Fig. 1. Synthliboramphus antiquus

1. 発見日時, 場所： 1980 年 7 月 26 日午後 3 時頃, 新潟市島見浜海岸波打ぎわ

2. 発見者: 新潟県中浦原県亀田町袋津 1867 長谷部七次

3. 鳥体の状況: 体重 $120 \mathrm{~g}$ であり, 全体に幼鳥羽をしており, 嘴峰が短かく, かつやわ らかであった。弱ってはいなかったが䬶は単独ではとれないよらであった。

各部の測定值は, 嘴峰 $11 \mathrm{~mm}$, 跗蹠 $25.5 \mathrm{~mm}$, 翼長 $121 \mathrm{~mm}$, 尾長 $34 \mathrm{~mm}$ であった。

4. 考 察: 本種の日本での繁殖地は天売島, 三貫島だけであり, その他に扣いて繁殖地 は確認されていない。

発見者によれば, 海上からはいあがってきたものであり, 当時は天候も睛れており, 風雨の 関係で流れついたものではなく，波によって 2 3 日の間に発見場所へ漂着したものであろろ。 海流の関俰からして北海道天売島で繁殖した個体が漂着することは考学られず（鳥体から判断 して海上から飛びあがり飛翔することは困難であると認めた），抢そらく新潟県の粟島（ウミ ネコとオオミズナギドリの集団繁殖地がある）か, 山形県の飛島（ウミネコの集団繁殖地があ

\footnotetext{
* 新潟県生活環境部自然保護課（干951 新潟市学校町通一番町 602）
} 
る）あたりで繁殖したものではないかと思われる。佐渡については海流の関係で本土側に漂着 することは殆んどないので（佐渡の漂着物は粟島沖を北上して行く）上記 2 ヶ所にし涪って よいと思われるが，繁殖条件としては粟島が最有力ではないかと思われる。

注：本種の保護捕獲については, 風間辰夫, 本間隆平（ともに新潟県生活環境部自然保護課勤務）が環 境庁長官の特別職務上の許可を得ており，これにより捕獲したものである。

\section{On a record of juvenile Antient Auk Synthliboramphus antiquus from Niigata}

\section{Tatsuo Kazama*}

A weakened Antient Auk Synthliboramphus antiquus in juvenile plumage was washed up on the beach of Niigata city, 26 July, 1980.

Judging from sea currents, its breeding place on Awashima I. is suggested, though not known so far in this sea area of Japan Sea.

* Nature Protection Section, Life Environmental Division, Niigata Pref., Goverment.

\section{お 知らせ}

第 3 回国際生態学会の開催案内が，当編集委員長あてに送られてきましたので，お知らせいたします。

(編集委員)

\section{Working Group on Granivorous Birds-INTECOL} 1982.

Third International Congress of Ecology will take place in Warsaw, Poland, 5-11 September

Working Group on Granivorous Birds-INTECOL is organizing inside the Congress special symposium on "Granivorous Birds". According to earliev planes, "The role of granivorous birds (especially Corvidae and Columbidae) in ecosystems" is suggested as a theme of the symposium. The theme will include the problems: 1) Populations dynamics, 2) Biomass and productions rates, 3) Energetics, 4) Impact of granivorous birds in ecosystems, 5) Managements of pest situation.

The time for oral contributions at the symposium is limited to 15 minutes. The programme of the symposium has be arranged at the end of 1981, i. e. based on titles and one page abstracts of papers. The poster presentation will be also possible.

All correspondence and request for scientific information should be send to: Prof. dr Jan Pinowski, Institute of Ecology PAN, Dziekanów Leśny, 05-150 Lomianki, Poland, or by telex 817378 IEPANPL

15 January 1981

Prof. dr Jan Pinowski

Chairman of Working Group 